\title{
Papillary microcarcinomas of the thyroid gland and immunohistochemical analysis of expression of p53 protein in papillary microcarcinomas
}

\author{
Demet Corapcioglu $^{\dagger 1}$, Serpil D Sak ${ }^{\dagger 2}$, Tuncay Delibasi*†1, Vedia Tonyukuk ${ }^{\dagger 1}$, \\ Nuri Kamel ${ }^{\dagger 1}$, Ali R Uysal ${ }^{\dagger 1}$, Savas Kocak ${ }^{\dagger 3}$, Semih Aydintug ${ }^{\dagger 3}$ and \\ Gurbuz Erdogan ${ }^{\dagger 1}$
}

\begin{abstract}
Address: ${ }^{1}$ Department of Endocrinology and Metabolism, Ankara University School of Medicine, Ankara, Turkey, ${ }^{2}$ Department of Pathology, Ankara University School of Medicine, Ankara, Turkey and ${ }^{3}$ Department of Surgery, Ankara University School of Medicine, Ankara, Turkey

Email: Demet Corapcioglu - demet.corapcioglu@temd.org.tr; Serpil D Sak - Serpil.D.Sak@medicine.ankara.edu.tr;

Tuncay Delibasi* - tuncay@delibasi.net; Vedia Tonyukuk - vedia.tonyukuk@temd.org.tr; Nuri Kamel - nuri.kamel@temd.org.tr;

Ali R Uysal - aruysal@interaktif.gen.tr; Savas Kocak - skocak@medicine.ankara.edu.tr; Semih Aydintug - saydintug@medicine.ankara.edu.tr; Gurbuz Erdogan - gurbuz.erdogan@temd.org.tr

* Corresponding author †Equal contributors
\end{abstract}

Published: 05 July 2006

Journal of Translational Medicine 2006, 4:28 doi:10.1 186/1479-5876-4-28
Received: 02 March 2006

Accepted: 05 July 2006

This article is available from: http://www.translational-medicine.com/content/4/I/28

(C) 2006 Corapcioglu et al; licensee BioMed Central Ltd.

This is an Open Access article distributed under the terms of the Creative Commons Attribution License (http://creativecommons.org/licenses/by/2.0), which permits unrestricted use, distribution, and reproduction in any medium, provided the original work is properly cited.

\begin{abstract}
Background: Thyroid papillary microcarcinoma (TPM) is defined according to WHO criteria as a thyroid tumor smaller than I-I.5 cm. TPMs are encountered in $0.5-35.6 \%$ of autopsies or surgical specimens where carcinoma had been unsuspected. The purpose of the present study was to evaluate patients who had TPMs in terms of clinical findings, histopathological features and immunohistochemical evidence of expression of the tumor suppressor gene $\mathrm{p} 53$.
\end{abstract}

Methods: A total of 44 patients with TPMs less than $1.0 \mathrm{~cm}$ in diameter were included in the study. The patients were evaluated clinically and the tumors were evaluated in terms of their histopathological and immunohistochemical features, including expression of p53.

Results: The female/male ratio was $2.8 / \mathrm{I}$, and the median age at time of diagnosis was 49 years (range 20-7I years). The maximum diameter of the smallest focus was $0.1 \mathrm{~mm}$, and that of the largest was $10 \mathrm{~mm}$ microscopically. The mean diameter of all tumors was $5.7 \mathrm{~mm}$. There was no correlation between tumor size and age or gender. Of the TPMs, 72 $\%$ were found in the right lobe, $24 \%$ in the left lobe and $4 \%$ in the isthmus. Fine-needle aspiration biopsy provided the diagnosis of TPM in only $43.2 \%$ of the patients. All patients were treated with surgery, with 20 undergoing conservative surgery, i.e. lobectomy or isthmusectomy, and 24 undergoing total thyroidectomy. Frozen section provided the diagnosis of TPM in only $56.8 \%$ of the patients. We found lymphocytic thyroiditis in $13.6 \%$ of patients, follicular variants in $11.9 \%$, capsular invasion in $26.8 \%$, lymph node involvement in $11.9 \%$, soft tissue metastases in the neck in $12.1 \%$ and multifocality in $31.7 \%$, and none of these were related to age or gender ( $p>0.05)$. No distant metastases were observed during approximately 10 years of follow up. We found p53 positivity in $34.5 \%$ of TPM tumors. However, p 53 expression was not statistically related to age or gender.

Conclusion: Our findings imply that TPMs may not be entirely innocent since they are associated with signs of poor prognosis such as capsular invasion, multifocal presentation, lymph node involvement and $\mathrm{p} 53$ positivity. Therefore, TPMs should be evaluated and followed like classical papillary cancers. 


\section{Background}

Thyroid papillary microcarcinoma (TPM), also known as occult papillary carcinoma (OPC), is usually defined as a thyroid tumor smaller than $1-1.5 \mathrm{~cm}[1,5]$. The term "occult thyroid papillary carcinoma" had been used before the WHO proposed a major diameter of $1 \mathrm{~cm}$ for occult papillary carcinoma, and renamed it as microcarcinoma [6]. Despite this proposal, different terms are currently used to define this thyroid cancer such as small, tiny, minute, minimal or incidental thyroid papillary cancer $[7,10]$.

TPMs are found at rates of $0.5-35.6 \%$ at autopsy or in surgical specimens where carcinoma had been unsuspected $[11,18]$. Some authors suggest that small tumors are very unlikely to be clinically significant even though up to 60 $\%$ of these lesions are associated with lymph node metastases which may be their presenting features $[19,20]$. TPMs that either have lymph node metastases or are multifocal with extracapsular invasion may be associated with lung metastases. Such cases are rare but they have significant morbidity and mortality $[20,21]$. Other authors take it as widely accepted that the recurrence and mortality risks of microcarcinomas are low $[22,24]$.

Given these somewhat mixed views regarding the clinical importance of TPMs, it seems desirable to study these tumors in detail, particularly in terms of any biochemical markers they exhibit. One such marker is the protein product of p53, a tumor suppressor gene. Mutations in or deletions of the p53 gene are among the most frequently detected genetic changes in human cancers $[25,26]$. The gene itself is located on the short arm of chromosome 17 [26]. The 553 protein is capable of inhibiting cell proliferation and transformation $[27,28]$. Several studies have shown a correlation between mutated p53 gene expression and degree of tumor differentiation $[29,30]$. It has also been reported that $\mathrm{p} 53$ gene expression is an indicator of poor prognosis, and might be important in the future for planning the treatment of TPMs $[31,32]$.

The purpose of the present study was to evaluate patients with TPMs in terms of clinical findings, histopathological features and immunohistochemical evidence of p53 expression, and to describe the relations between these.

\section{Patients and methods}

We reviewed the clinical records of 255 consecutive patients who underwent surgery for thyroid cancer between 1994 and 2002 at Ankara University Hospital in Ankara, Turkey. Of these patients, 44 had tumors that were less than $1.0 \mathrm{~cm}$ in diameter, and these tumors were classified as microcarcinoma. Of these 44 patients, 29 had pathological preparations that we were able to stain for p53 expression. The specimens of the 15 other patients could not be stained for various reasons, including inadequate pathological slides. This retrospective study was performed in accordance with the ethical requirements of our institution. All histopathologic and cytologic materials were reviewed by the same pathologist and were evaluated according to WHO recommendations [6].

The variables examined in this study included age and gender of the patient, tumor size, histological features (multifocality, invasion of the thyroid capsule, etc.), the presence of distant or regional metastases and the expression of $\mathrm{p} 53$ protein.

To detect p53 gene expression immunohistochemically, we used a monoclonal antibody that reacts with both mutant and wild type 553 protein (clone DO7+BP53-12, Neomarkers, CA, USA). Sections $4-6 \mu \mathrm{m}$ thick were cut from tissue fixed with $10 \%$ buffered formalin, embedded in paraffin blocks and treated with xylene for deparaffinization and were rehydrated in decreasing alcohol concentrations. Antigen retrieval was performed by heating samples in citrate buffer ( $\mathrm{pH}$ 7.0) in a pressure cooker. Endogenous peroxidase activity was blocked by $\mathrm{H}_{2} \mathrm{O}_{2}$. A streptavidin biotin horseradish peroxidase system with a computerized staining apparatus (Ventana, Nexus) was used for staining procedures. Antibody dilution was 1:100. Diaminobenzidine (DAB) was used as a chromogen and counterstaining was performed with hematoxylin. A larynx carcinoma with known p53 expression served as the positive control. For the negative control, the procedures were the same but PBS was substituted for the primary antibody. The slides were evaluated by light microscopy, and brown nuclear staining was accepted as positive. The most extensively stained area was examined and the percentage of positively stained tumor cells was estimated.

Statistical analyses were performed with SPSS v.11.0 software (SPSS Inc., Chicago, USA).

\section{Results}

Among the 44 patients in the study, the female to male ratio was 2.8/1, and the median age at time of diagnosis was 49 years (range 20-71 years). Mean follow-up period of the patients was approximately 10 years. None of the patients had previously received radiation therapy directed at cervical lymph nodes and none had a family history of thyroid cancer.

The maximum diameter of the smallest focus was $0.1 \mathrm{~mm}$, and that of the largest was $10 \mathrm{~mm}$ microscopically. The mean diameter of all tumors was $5.7 \mathrm{~mm}$, and the mean diameters in males and females were $5.4 \mathrm{~mm}$ and $5.8 \mathrm{~mm}$, respectively. When the patients were classified as younger or older than 50 years, the mean diameter of TPMs was 5.5 
$\mathrm{mm}$ in the younger patients and $5.8 \mathrm{~mm}$ in the older ones. Tumor size was not related to age or gender ( $p>0.05)$. Of the TPM foci, $72 \%$ were found in the right lobe, $24 \%$ in the left lobe and $4 \%$ in the isthmus.

Table 1 compares fine needle aspiration biopsy (FNAB) and frozen section in terms of detectability for TPM in our patients. FNAB provided the diagnosis of papillary carcinoma in only $43.2 \%$ of the TPM tumors. All patients underwent surgery. Conservative methods, i.e. lobectomy and isthmusectomy, were used in 20 patients and total thyroidectomy was performed in 24 patients. Frozen section studies provided the diagnosis of TPM in only $56.8 \%$ of the patients that were examined by frozen section. Of the patients with malignancy demonstrated by FNAB, 6.8 $\%$ were diagnosed with benign disease on frozen section.

Following surgery, the 24 patients who had bilateral total thyroidectomy received $\mathrm{I}^{131}$ ablation therapy. The dosage of $\mathrm{I}^{131}$ ranged from 75 to $200 \mathrm{mCi}$. Thyroid hormone replacement therapy (LT4) was continuously administered to these patients as well as to the 20 patients who had received lobectomy or isthmusectomy. The dosage of LT4 ranged from 100 to $175 \mu \mathrm{g}$.

Table 2 shows the histopathologic and other features of the tumors. Due to their small size most TPMs were not detected grossly. All tumors exhibited the characteristic features of papillary carcinoma such as ground-glass nuclei with nuclear grooves and occasional nuclear inclusions. We found lymphocytic thyroiditis in $13.6 \%$ of patients, follicular variants in $11.9 \%$, capsular invasion in $26.8 \%$, lymph node involvement in $11.9 \%$, soft tissue metastases in the neck in $12.1 \%$ and multifocality in 31.7 $\%$, and none of these were related to age or gender ( $\mathrm{p}>$ 0.05). During approximately 10 years of follow-up, no distant metastases were observed and there were no deaths.

We found p53 positivity in $34.5 \%$ of the TPM tumors. There was no correlation between p53 expression and sex, age, histological variant of tumors, capsular invasion, multifocality or presence of local or regional lymph node metastases $(\mathrm{p}>0.05)$ (Table 2$)$.

\section{Discussion}

When we examine the cases of TPM in our patients and in the literature, we find that despite their small size, TPMs are not biologically innocent in all cases and may show capsular invasion, multifocality, regional lymph node metastases and p53 protein positivity at the time of diagnosis. These features associated with a portion of TPMs are the poor prognostic factors for differentiated thyroid malignancies (DTC). TPMs might therefore need to be evaluated and followed in the same way as classical thyroid papillary carcinomas.

Among our patients, females appeared to be more frequently affected, as is the case in other types of papillary carcinoma. Our female to male ratio was $2.8 / 1$, similar to that in Salvadori's microcarcinoma study [34]. Kasai and Sakamoto have reported an even higher female to male ratio of $9 / 1$ in their series [7]. In contrast, some authors reported that OPC was more common in men than in women, although non-occult papillary carcinoma was more common in women [12,35]. These latter findings favor the view that OPC is a different clinical entity and not the early stage of non-occult papillary carcinoma.

The median age at time of diagnosis of TPM was 49 years in our patients. Our patients' ages ranged from 20 to 71, a wide range similar to those previously reported in the literature $[14,15]$.

With fine needle aspiration biopsy (FNAB) of the thyroid we were able to detect malignancy in only $43.8 \%$ of our TPM tumors. This ratio is slightly lower than some previously reported rates, which range from $35.8 \%$ to $55.5 \%$ $[36,41,46]$. The reason for our lower rate of carcinoma detection with FNAB may be the smaller sizes of the tumors we have examined. Tumors with diameters less than $10 \mathrm{~mm}$ have been evaluated in our present study whereas tumors up to $15 \mathrm{~mm}$ in diameter have been included in most of the previous studies. Still, our rate is more or less close to the $49.3 \%$ rate of carcinoma detection in OPC with ultrasound-guided FNAB reported by Jen Der Lin et al [36]. The rate of detection of carcinoma in frozen section examination is also low (57\%) in our study. Small tumor size might be responsible for this as well. In the study by Jen Der Lin et al., malignancy was detected in $73 \%$ of the OPC cases on frozen section examination [36].

Table I: Comparison of FNAB and frozen section in terms of their detection of TPM

\begin{tabular}{llll}
\hline & FNAB (\% of patients) & Frozen section (\% of patients) & $\begin{array}{l}\text { Postoperative pathology (\% of } \\
\text { patients) }\end{array}$ \\
\hline TPM & 43.2 & 56.8 & 100 \\
Follicular variant & 0 & 0 & 11.9 \\
\hline
\end{tabular}


Table 2: Histopathologic and other features of the tumors in this study

\begin{tabular}{|c|c|c|}
\hline & (n) & $\%$ \\
\hline Lymphocytic thyroiditis & $6(44)$ & 13.6 \\
\hline Follicular variant & $5(42)$ & 11.9 \\
\hline Capsular invasion & $\mathrm{II}(4 \mathrm{I})$ & 26.8 \\
\hline Lymph node involvement & $5(42)$ & 11.9 \\
\hline Soft tissue metastases in the neck & $5(4 I)$ & 12.1 \\
\hline Distant metastases & 0 & 0 \\
\hline Multifocality & $\mid 3(4 \mid)$ & 31.7 \\
\hline p53 positivity & $10(29)$ & 34.5 \\
\hline
\end{tabular}

With regard to pathological features, capsular invasion was observed in $26.8 \%$ of our patients. Salvadori et al. reported an incidence of $15.2 \%$ of capsular invasion in a series that included tumors larger than those evaluated in our study [34]. Furmanckuk et al. reported that one patient out of 10 with papillary or mixed papillary-follicular OPC had capsular invasion [16]. Harach et al. reported a $17 \%$ rate of capsular invasion in their series [12]. They observed a statistically significant association between tumor size and capsular invasion, larger tumors being more likely to invade the capsule [12].

The occurrence of multiple foci of carcinoma in OPC is thought to be due to intrathyroidal tumoral invasion through lymphatics rather than neoplastic transformation of multiple clones of cells located in various parts of the thyroid [37]. Multiple carcinomatous foci can sometimes be observed in both lobes of the thyroid $[3,12,14,15]$. Multiple foci of papillary carcinoma were identified in $31.7 \%$ of TPM tumors in our series. The incidence of multifocality in OPC has been reported as $35.6 \%$ by Harach [12], 30.4 \% by Yamamoto [14], $20.6 \%$ by Pelizzo [15], $31.5 \%$ by Furmanckuk [16], and $23.6 \%$ by Salvadori [34]. Hazard has noted that multifocality is associated with metastases [38]. A small tumor can therefore be multifocal and carry the risk of metastasis. No relationship has been reported, so far, between the multiplicity of tumors and age or gender, and we found no such relation in our patients.

We found lymphocytic infiltration within the tumor stroma or around the tumor foci in six patients $(13.6 \%$ of TPM tumors). Harach et al. have reported a rate of $27.7 \%$ for lymphocytic reaction within the tumor stroma or around the invading tumor islands [12]. Such lymphocytic infiltration was associated with invasive OPC and larger tumors, and it was thought to represent host reaction to tumor. The occurrence of lymphocytic infiltration limited to tumor periphery therefore seems unrelated to lymphocytic thyroiditis [12]. However, Hirabayashi and Lindsay have reported a higher than expected frequency of non-occult papillary carcinoma in patients with thyroiditis [39], and it has also been reported that the presence of lymphocytic thyroiditis around tumors indicates a good prognosis [40].

Lymph node metastases are characteristic features of all types of papillary carcinoma including OPC. However, they are of doubtful clinical significance. They are thought to indicate early recurrence and poor prognosis by some authors $[31,42]$. On the other hand, other investigators report that regional lymph node metastases do not affect survival $[43,45]$. Regional lymph node metastases were detected in $11.9 \%$ of our patients and this is an incidence that is well within previously reported ranges. Frequencies of lymph node metastases in OPC have been reported as zero by Pelizzo et al. [15], as $0.3 \%$ by Yamamoto et al [14], as $23 \%$ by Hazard et al. [38], as $39 \%$ by Woolner et al. [41], as $40 \%$ by Hubert et al. [10], and as $42 \%$ by Kasai et al. [7]. The highest reported frequency of lymph metastases is $70.8 \%$ in the study by Salvadori et al. on OPC patients with tumor sizes less than $15 \mathrm{~mm}$ [34].

The presence of distant metastases indicates a poor prognosis for OPC [31]. Although distant metastases are rare in OPC as deduced from follow-up [34] or from findings

Table 3: Persentages in $\mathrm{p} 53$ positive and $\mathrm{p} 53$ negative patients according to histopathologic features.

\begin{tabular}{lccc}
\hline & $\mathrm{p} 53$ positive $\mathrm{n}(\%)$ & $\mathrm{p} 53$ negative $\mathrm{n}(\%)$ & Total $\mathrm{n}$ \\
\hline Lymphocytic thyroiditis & $2(33.3)$ & $4(66.7)$ & 6 \\
Follicular variant & $2(40.0)$ & $3(60.0)$ & 5 \\
Capsular invasion & $5(45.5)$ & $3(54.5)$ & 11 \\
Lymph node involvement & $3(60.0)$ & $2(40.0)$ & 5 \\
Soft tissue metastases in the neck & $4(66.7)$ & $2(33.3)$ & 5 \\
Multifocality & $7(53.8)$ & $6(46.2)$ & 13 \\
\end{tabular}


in autopsy series [14-16], metastases to lung, trachea, pleura, vertebral column, pericardium, cerebrum, femur, humerus and mediastinum have been reported $[1,46,53]$. The smallest reported tumor with distant metastases was $3 \mathrm{~mm}$ in diameter [46]. No distant metastases were present in our patients with TPM during a follow-up period of approximately 10 years.

Similar to previous reports $[14,15]$ tumors were located in the right lobe in $72 \%$ of our patients, in the left lobe in $24 \%$, and in the isthmus in $4 \%$. Although the significance of this pattern of uneven distribution has not yet been clarified, nodules located in the right thyroid lobe may deserve a more detailed evaluation.

Tumor size has been reported as an important prognostic factor in papillary and follicular carcinomas of the thyroid [31]. In two autopsy series the mean diameter of occult thyroid carcinoma was $1.7 \mathrm{~mm}$ and $1.98 \mathrm{~mm}$, respectively $[14,16]$. Tumor diameters in our series ranged from 1 to $10 \mathrm{~mm}$ (mean $5.7 \mathrm{~mm}$ ). No association was found between tumor size and age or gender in those autopsy series $[14,16]$. The same was true in our series. One of the larger recent studies reported that approximately one in four patients with a papillary thyroid cancer no more than $1.5 \mathrm{~cm}$ in size developed persisting or relapsing disease after surgery [62].

Over-expression of p53 and mutations in the p53 gene are more frequent in poorly differentiated and anaplastic carcinomas than in well-differentiated papillary and follicular carcinomas $[32,54,63]$. Also, p53 gene expression is reported to be a significant and independent prognostic factor for cause-specific and crude survival in these patients [31,32]. Anaplastic changes following insufficient radioiodine therapy have been shown to be associated with p53 gene mutation in differentiated thyroid carcinoma [64]. There is a higher rate of p53 gene mutation in the tall cell variant of papillary thyroid carcinoma than in the common variant [65]. Immunohistochemical detection of $\mathrm{p} 53$ protein by means of prolonged half-life is thought to be associated with the occurrence of p53 gene mutations since the prolongation of the protein's half-life has been regarded as a direct consequence of structural changes attributable to missense point mutations [25]. More recent investigations have demonstrated that wild type p53 can be stable up to approximately 24 hours [33]. The mutated p53 protein can remain present in tissues for longer than 24 hours whereas the normal protein cannot. Of our patients, only $34.5 \%$ tested positive for p53 and this was not significantly associated with age, gender, capsular invasion, lymph node metastases, multifocality, tumor location, histologic variant of tumor, or tumor diameter.

\section{Conclusion}

Our findings in this study imply that TPMs may not be innocent since they can be associated with indicators of poor prognosis such as capsular invasion, multifocal presentation, lymph node involvement and p53 positivity. Therefore, thyroid papillary microcarcinomas should be evaluated and followed like other papillary cancers. In order to reach a clearer understanding of the relationships between p53 positivity and TPM, p53 gene mutations should be detected by using PCR methods, and clinical outcomes of these mutations should be evaluated in longitudinal studies in the same patients.

\section{References}

I. Allo MD, Christianson W, Koivunen D: Not all "occult" papillary carcinomas are "minimal". Surgery 1988, 104:97I-6.

2. Boehm T, Rothouse L, Wartofsky L: Metastatic occult follicular thyroid carcinoma. JAMA 1976, 235:2420-I.

3. Bondeson L, Ljungberg O: Occult thyroid carcinoma at autopsy in Malmö, Sweden. Cancer 1981, 47:319-23.

4. Bondeson L, Ljungberg O: Occult papillary thyroid carcinoma in young and aged. Cancer 1984, 53:1790-2.

5. Franssila KO, Harach R: Occult papillary carcinoma of the thyroid in children and young adults. Cancer 1986, 58:715-19.

6. Hedinger C: In WHO International Histological Classification of Tumors. 2nd edition. Berlin: Springer; 1988:9-II.

7. Kasai N, Sakomoto A: New subgroupig of small thyroid carcinomas. Cancer 1987, 60:1767-70.

8. Burguera B, Gharib H: Thyroid incidentalomas: Prevalence, diagnosis, significance, and management. Endocrinol Metab Clin North Am 2000, 29:187-203.

9. Koischwitz D: Ultrasound of the neck. Radiol Clin North Am 2000, 38: 1029-45.

10. Hubert JP, Kiernan PD, Beahrs OH: Occult papillary carcinoma of thyroid. Arch Surg 1980, I 1 5:394-98.

II. Farooki MA: Epidemiology and pathology of cancer of the thyroid. I. Material, methods and results. Int Surg 1969, 5 I:232-43.

12. Harach RH, Franssila KO, Wasenius V: Occult papillary carcinoma of the thyroid. A"normal" finding in Finland. A systematic autposy study. Cancer 1985, 56:53I-8.

13. Delides GS, Elemenoglou J, Lekkas CH, Kittas CH, Evthimiou C: Occult thyroid carcinoma in a Greek population. Neoplasma 1987, 34: II9-25.

14. Yamamoto $\mathrm{Y}$, Maeda $\mathrm{T}$, Izumi $\mathrm{K}$, Otsuka H: Occult papillary carcinoma of the thyroid. A study of $\mathbf{4 0 8}$ autopsy cases. Cancer 1990, 65: I I73-9.

15. Pelizzo MR, Piotto A, Rubello D, Casara D, Fassina A, Busnardo B: High prevelence of occult papillary thyroid carcinoma in a surgical series for benign thyroid disease. Tumori 1990, 76:255-7.

16. Furmancuk AW, Roussak N, Ruchti C: Occult thyroid carcinomas in the region of Minsk, Belarus. An autopsy study of 215 patients. Histopathology 1993, 23:319-25.

17. Komorowski RA, Hanson GA: Occult thyroid pathology in the young adult. An autopsy study of 138 patients without clinical thyroid disease. Hum Pathol 1988, 19:689-96.

18. Lang W, Borrusch H, Bauer L: Occult carcinomas of the thyroid. Evaluation of 1020 sequential autopsies. Am J Clin Pathol 1988, 90:72-6.

19. Sugino K, Ito K, Ozaki O, et al.: Papillay microcarcinoma of the thyroid. J Endocrinol Invest 1998, $21: 445-8$.

20. Baudin E: Microcarcinoma of the thyroid gland: the GustaveRoussy Institute experience. Cancer 1998, 83:553-9.

21. Moosa M, Mazzaferri EL: Occult thyroid carcinoma. Cancer 1997 , 9:87-90.

22. Ain KB: Papillary thyroid carcinoma etiology, assessment and therapy. Endocrinol Metab Clin North Am 1995, 24:7I I-I5.

23. Noguchi S, Yamashita H, Murakami N, Nakayama I, Toda M, Kawamoto H: Small carcinomas of the thyroid - a long term follow up of 867 patients. Arch Surg 1996, 31:87-91. 
24. Hay ID, Grant CS, Van Heerden JA, Goellner JR, Ebersold JR, Bergstralh E): Papillary thyroid microcarcinoma: a study of $\mathbf{5 3 5}$ cases observed in a $\mathbf{5 0}$ year period. Surgery 1992, I I 2: I I39-47.

25. Selivanova G, Wiman KG: P53: a cell cyle regulator activated by DNA damage. Adv Cancer Res 1995, 66: 143-80.

26. Levine AJ, Momand J, Finlay CA: The p53 tumor suppressor gene. Nature 1991, 35 I:453-6.

27. Martinez J, Georgof I, Levine AJ: Cellular localization and cell cycle regulation by a temperature-sensitive $\mathrm{p} 53$ protein. Genes Dev 1991, 5: 151-9.

28. Finlay CA, Hinds PW, Levine AJ: The $\mathbf{p} 53$ proto-oncogene can act as a suppressor of transformation. Cell 1989, 57:1083-93.

29. Dobashi $Y$, Sakamoto A, Sugimura H, et al.: Overexpression of p53 as a possible prognostic factor in human thyroid carcinoma. Am J Surg Pathol 1993, I 7:375-8I.

30. Donghi R, Longoni A, Pilotti S, Michieli P, Della-Porta G, Pierotti MA: Gene p53 mutations are restricted to poorly differentiated and undifferentiated carcinomas of the thyroid gland. J Clin Invest 1993, $91: 1753-60$.

31. Godballe C, Asschenfelt P, Jorgensen KE, et al:: Prognostic factors in papillary and follicular thyroid carcinomas: p53 expression is a significant indicator of prognosis. Laryngoscope 1998 108:243-9.

32. Nishida T, Nakao K, Hamaji M, Nakahara MA, Tsumimoto M: Overexpression of p53 protein and DNA content are important biologic prognostic factors for thyroid cancer. Surgery 1996, I 1 9:568-75.

33. Fritsche M, Haessler $C$, Brandner G: Induction of nuclear accumulation of the tumor-suppressor protein p53 by DNA-damaging agents. Oncogene 1993, 8:307-18.

34. Salvadori B, Del Bo R, Pilotti S, Grassi M, Cusumano F: "Occult" Papillary Carcinoma of the Thyroid: a Questionable Entity. Eur J Cancer 1993, 29A: I8I7-20.

35. Sampson RJ, Key CR, Buncher CP, Lijima S: Smallest forms of papillary carcinoma of the thyroid: A study of 141 microcarcinomas less than $0.1 \mathrm{~cm}$ in greatest dimention. Arch Pathol 1971, 91:334-9.

36. Lin JD, Huang BY, Chao TC, Hsueh C: Diagnosis of Occult Thyroid Carcinoma by Thyroid Ultrasonography with Fine Needle Aspiration Cytology. Acta Cytologica 1997, 41:175I-56.

37. Fialkow PJ: The Origin and Development of Human Tumors Studies with Cell Markers. N Eng J Med 1974, 291:26-33.

38. Hazard JB: Small papillary carcinoma of the thyroid: A study with special reference to so-called nonencapsulated sclerosing tumor. Lab Invest 1960, 9:86-97.

39. Hirabayashi RN, Lindsay S: The relationship of Thyroid carcinoma and chronic Thyroiditis. Surg Gynecol Obstet 1965, | 2 |:243-52.

40. Shalini G, Aneeta $P$, Angela $F$, et al.: Infiltration of differentiated thyroid carcinoma by proliferating lymphocytes is associated with improved disease-free survival for children and young adults. J Clin Endocrinol Metab 200I, 86: 1346-54.

41. Woolner LB, Lemmon ML, Beahrs OH, Black BM, Keating FR: Occult papillary carcinoma of the thyroid gland: $A$ study of 140 cases observed in a $\mathbf{3 0}$ year period. J Clin Endocrinol 1960, 20:89-105.

42. Yamashita $\mathrm{H}$, Noguchi $\mathrm{S}$, Murakami $\mathrm{N}$, et al.: Extracapsular invasion of lymph node metastasis. Cancer 1999, 86:842-9.

43. Schoder DM, Chambors A, France CJ: Operative strategy for thyroid cancer: is total thyroidectomy worth the price. Cancer 1986, 58:2320-8.

44. Vickery AL, Wang C, Walker AM: Treatment of intrathyroidal papillary carcinoma of the thyroid. Cancer 1987, 60:2587-95.

45. Rossi R, Cady b, Silverman ML, Wool MS, Horner TA: Current results of conservative surgery for differentieted thyroid carcinoma. World J Surg 1986, 10:612-22

46. Strate M, Lee EL, Chiders JH: Occult papillary carcinoma of the thyroid with distant metastases. Cancer 1984, 54:1093-100.

47. Harach HR, Franssila KO: Occult Papillary Carcinoma of the Thyroid Appearing as Lung Metastasis. Arch Path Lab Med I984, 108:529-30.

48. Laskin WB, James LP: Occult papillary carcinoma of the thyroid with pulmonary metastases. Hum Pathol 1983, I 4:83-5.

49. Fend f, Gruber U, Fritzsche H, Rothmund J, Breitfellner G, Mikuz G: Occult papillary carcinoma of the thyroid with pulmonary lymphengitic spread diagnosed by lung biopsy. Klin Wochenschr 1989, 67:687-90

50. Paksoy N, Ozturk H, Demircan A, Artvinli M: Occult papillary carcinoma of the thyroid presenting as an intratracheal tumour. Eur J Surg Oncol 1994, 20:694-5.

5I. Michie HR, O'Bryan-Tear CG, Marsh H, Glazer G: Cerebral metastases from occult papillary carcinoma of the thyroid. Br J Surg 1987, 74:647.

52. Lloyd RV, Bieierwaltes WH: Occult sclerosing carcinoma of the thyroid. South Med J 1983, 76:437-9.

53. Jancic-Zguricas M, Jankovic R: Occult papillary carcinoma of the thyroid gland revealed by cancer pericarditis. Pathol Res Pract 1986, $181: 761-6$

54. Matias-Guiu X, Cuatrecasas M, Musulen E, Prat J: p53 expression in anaplastic carcinomas arising from thyroid papillary carcinomas. J Clin Pathol 1994, 47:337-9.

55. Kikuchi S, Hiraide H, Tamakuma S, Yamamoto M: Expression of wild-type p53 tumor suppressor gene and its possible involvement in the apoptosis of thyroid tumors. Surg Today 1997, 27:226-33.

56. Chen BK, Ohtsuki Y, Furihata M, Takeuchi T, Iwata J, Liang SB, Sonobe $\mathrm{H}$ : Co-overexpression of $\mathrm{p} 53$ protein and epidermal growth factor receptor in human papillary thyroid carcinoma correlated with lymph node metastasis, tumor size and clinicopathologic stage. Int J Oncol 1999, 15:893-8.

57. Williams ED: Mechanisms and pathogenesis of thyroidcancer in animals and man. Mutat Res 1995, 333:123-9.

58. Vecchio G, Santoro M: Oncogenes and thyroid cancer. Clin Chem Lab Med 2000, 38: I I3-6.

59. Gillenwater AM, Weber RS: Thyroid carcinoma. Cancer Treat Res 1997, 90:149-69.

60. Fagin JA: Tumor suppressor genes in huan thyroid neoplasms: p53 mutations are associated undifferentiated thyroid cancers. J Endocrinol Invest 1995, 18:140-2.

6I. Karlsson MG, Hardell L, Hallquist A: No association between immunuhistýchemical expression of p53, c-erbB-2, Ki-67, estrogen and progesterone receptors in female papillary thyroid cancer and ionizing radiation. Cancer Lett 1997, 120:173-7.

62. Pellegriti G, Scollo C, Lumera G, Regalbuto C, Vigneri R, Belfiore A: Clinical behavior and outcome of papillary thyroid cancers smaller than $1.5 \mathrm{~cm}$ in diameter: study of 299 cases. I Clin Endocrinol Metab 2004, 89:37I3-20.

63. Michie HR, O'Bryan-Tear CG, Marsh H, Glazer G: Cerebral metastases from occult papillary carcinoma of the thyroid. Br J Surg 1987, 74:647.

64. Nobuko S, Kiyoto A, Takao A, et al.: Anaplastic changes associated with p53 gene mutation in differentiated thyroid carcinoma after insufficient radioactive iodine (II3I) therapy. Thyroid 2000, 10:975-9.

65. Ruter A, Dreifus J, Jones M, Nishiyama R, Lennquist S: Overexpression of p53 in tall cell variants of papillary thyroid carcinoma. Surgery 1996, 120:1046-50.

Publish with Bio Med Central and every scientist can read your work free of charge

"BioMed Central will be the most significant development for disseminating the results of biomedical research in our lifetime. "

Sir Paul Nurse, Cancer Research UK

Your research papers will be:

- available free of charge to the entire biomedical community

- peer reviewed and published immediately upon acceptance

- cited in PubMed and archived on PubMed Central

- yours - you keep the copyright 